\title{
IAMJ
}

INTERNATIONAL

AYURVEDIC

MEDICAL JOURNAL

Case Report

ISSN: 2320-5091

Impact Factor: 6.719

\section{A SINGLE CASE STUDY ON THE EFFECT OF AYURVEDIC MANAGEMENT IN TIMIRA W.S.R. TO MYOPIA - A CASE STUDY}

\author{
Kavita Rathore $^{1 *}$, Shamsa Fiaz ${ }^{2}$ \\ P.G. Scholar, Department of Shalakya Tantra in National Institute of Ayurveda Jaipur, Rajasthan, India \\ Professor and HOD, Department of Shalakya Tantra in National Institute of Ayurveda Jaipur, Rajasthan, India
}

Corresponding Author: kavitarathore2138@gmail.com

https://doi.org/10.46607/iamj3709072021

(Published Online: July 2021)

Open Access

(C) International Ayurvedic Medical Journal, India 2021

Article Received: 06/06/2021 - Peer Reviewed: 13/06/2021 - Accepted for Publication: 18/06/2021

Check for updates

\begin{abstract}
Introduction - Myopia is the most common Refractive error of the eye seen in children and young adults and it has become more prevalent in recent years and is a cause of concern the world over. Myopia commonly referred to as near or shortsightedness. Some of the clinical features of Vataja Timira can be correlated with Myopia. Timira is counted under the Drishtigata Rogas ${ }^{[1]}$ described by Sushruta. Timira involving first and second patala in terms of symptoms, anatomical structures involved and the pathogenesis of the disease. Timira begins with the blurring of vision gradually leading to the deterioration of eyesight. Shastrokta lakshanas of Vatika Timira such as bhramantiva sa pashyati, aavil darshan, vyaavidha darshan, aruna darshan ${ }^{[2]}$. Materials and Methods - A 20-year-old male, came to Shalakya Tantra OPD in National Institute of Ayurveda, deemed to be University Jaipur (R.J.), with chief complaints of defective vision for distance in both eyes, pain in both eyes and watering from both eyes since 4 months. He was treated with Nasya, Netra Pariseka, one sitting of Tarpana, Triphala guggulu, Patoladi eyedrops and Netramritam eyedrops. Result - At the end of the study, improvement in the visual acuity in both eyes, improvement in pain in both eyes and watering from both eyes have reduced. Conclusion -Thus, it can be concluded that Ayurvedic treatments are helpful to control Myopia.
\end{abstract}

Keywords: Myopia, Nasya, Tarpana, Netra pariseka, Timira, Triphala Guggulu. 


\section{INTRODUCTION}

Ayurveda is an eternal science and deep ocean of knowledge that help to achieve longevity. Its main aim is to protect the health of the healthy person and cure the disease of the diseased. Myopia is a major public health problem about the eye that entails substantial societal, educational, personal and economic impact. Myopia is a type of refractive error in which rays of light coming from infinity are focused in front of the retina when accommodation is at rest ${ }^{[3]}$. Grading of Myopia:

1) Low Myopia - error is equal or less than -3D

2) Moderate Myopia - error is between -3D to -6D

3) High Myopia - error is equal and more than $-6 \mathrm{D}^{[4]}$ Myopia is highly prevalent in our society, affecting at least $25 \%$ of the adult population in the United States. Various surveys in India have found myopia prevalence ranging from 6.9 to $19.7 \%$. Furthermore, its prevalence may be increasing over time as suggested by some studies in various countries. Due to the significance of myopia as a global public health concern, it was chosen as a priority for vision 2020, the World Health Organisation global initiative for the elimination of avoidable blindness by the year 2020. Recent studies and W.H.O. reports indicate that refractive errors are the first cause of visual impairment and the second cause of visual loss worldwide as 43 per cent of visual impairments are attributed to refractive errors. In modern science, the treatment options of myopia include spectacles, contact lenses, and Lasik surgery which are very expensive ${ }^{[5]}$. Hence to provide an efficient and better cure by the cost-effective method through Ayurveda, this study is planned which incorporates Kriya Kalpa procedure, an oral drug to tackle it efficiently. Snehana is the best treatment for Vataja disorders hence Tarpana is selected in the present disease. Tarpana is topical therapy in which medicated ghee is retained in the eyes by a retention wall made from Urada dal flour which has been recommended in improving the Drishtibala of the eyes as it has Roga Nivruti and Vyadhi Vinashakar properties.

In Ayurveda, the clinical features related to visual disturbance are seen in Drishtigata Rogas. Hence, all cases of visual disturbance can be included under the broad heading of Timira-Kanch-Linganasha group. Clinical features of Timira (First and Second Patala) can be correlated with the most important refractive error, which is, myopia. In the Ayurvedic classics, we find the concept of Chakchusya and many drugs, and the therapeutic procedures explained which increases visual acuity as well as improve the health of the eye. Nasya Karma is one among the procedures of Panchkarma that is specifically desired in Urdhwajatrugata (supraclavicular) diseases. All the efforts should be made to strengthen by procedures like Nasya, Netra pariseka and Tarpana and so on. The nose is the gateway of drug administration in the case of Urdhwajatrugata Rogas and Nasya is the only procedure that directly affects all the Indriyas.

\section{CASE HISTORY}

A fully conscious oriented male aged 20 years, has visited Shalakya tantra OPD, National Institute of Ayurveda Deemed to be University, Jaipur with chief complaints of defective vision for distance in both eyes, pain in both eyes and watering from both eyes for 4 months.

History - have no relevant history was found.

Family history - have no family history was found.

Personal History - the patient was Vegetarian, normal Appetite, Bowel history Regular, Normal Micturition and sleeps is sound sleep.

On eye examinations - by Torchlight and Slit lamp, we found. 
Table 1:

\begin{tabular}{|l|l|l|}
\hline EYE PARTS & OD & OS \\
\hline Lids, Lashes & Normal & Normal \\
\hline Conjunctiva & Normal & Normal \\
\hline Cornea & Normal & Normal \\
\hline Pupil & Normal Reaction & Normal Reaction \\
\hline Anterior Chamber & Normal & Normal \\
\hline Lens & No significant changes & No significant changes \\
\hline
\end{tabular}

Table 2: Visual acuity:

\begin{tabular}{|l|l|l|}
\hline & Right Eye & Left Eye \\
\cline { 2 - 3 } & Before Treatment & Before Treatment \\
\hline DVunaided & $6 / 24$ & $6 / 24$ \\
\hline BCVA & $6 / 12$ & $6 / 12$ \\
\hline PH & $6 / 9$ & $6 / 9$ \\
\hline NV unaided & $\mathrm{N} / 6$ & $\mathrm{~N} / 6$ \\
\hline
\end{tabular}

TREATMENT - Shodhana and Shamana both treatments were given to the patient. Treatment Protocol: Internal medicine - 30 days, Nasya - 7 days, Netra pariseka -7 days, Tarpana -7 days
Netramritam and Patoladi ghrita Eyedrops - 30 days - Spectacle correction for Distance vision Right eye --0.75 DS, Left eye $--0.50 \mathrm{DS}$

Table 3: Therapeutics intervention adopted.

\begin{tabular}{|l|l|l|l|}
\hline PROCEDURE & DRUGS & DURATION & DOSAGE \\
\hline Internal Medicine & Triphala guggulu & 30 days & $700 \mathrm{mg}$ after meal BID \\
\hline Eyedrops & Netramritam Eyedrop & 30 days & $1-1$ drop BID \\
\cline { 2 - 4 } & Patoladi Ghrita Eyedrop & 30 days & $1-1$ drop at night-time \\
\hline Nasya & Shadbindu taila & 7 days & $6-6$ drops each nostril \\
\hline Netra pariseka & $\begin{array}{l}\text { Triphala }-2 \text { gm } \\
\text { Yashathi }-2 \text { gm }\end{array}$ & 7 days & As required \\
\hline Tarpana & Patoladi Ghrita & 7 days & As required \\
\hline
\end{tabular}

Nasya was done with Shadbindu taila. Six drops of oil were instilled in each nostril in the morning time for seven days. Netra pariseka was done with Triphala churna and Yashthi churna along with Nasya karma for seven days in the morning time. Tarpana was done with Patoladi ghrita in the morning time for seven days. Triphala guggulu $700 \mathrm{mg}$ was started from the first day and was continued for 30 days with lukewarm water after meal. Netramritam eyedrop and Patoladi eyedrop were started from the first day and was continued for 30 days. 
Table 4: Ingredients of Drugs

Patoladi Ghrita ${ }^{[6]}$

S.No.

1

2

3

4

5

6

7

8

9

10

11

12

13

14

15

16

17

18

19

20
Drugs

Nimba

Patola

Kutaki

Daruharidra

Ushira

Haritaki

Vibhitaki

Aamalaki

Vasa

Dhanvayas

Parpataka

Trayanti

Mustaka

Bhunimba

Yashthimadhu

Kutaja

Udichya

Chandana

Pippali

Ghrita

Table 5:

Shadbindu Taila ${ }^{[7]}$

S.No.

1

2

3

4

5

6

7

8

9

10

11

12

13

\begin{tabular}{|l}
\hline Drugs \\
\hline Tila Taila \\
\hline Aja ksheera \\
\hline Bhringraj \\
\hline Eranda \\
\hline Tagara \\
\hline Shatapushpa \\
\hline Jivanti \\
\hline Rasna \\
\hline Saindhava \\
\hline Vidanga \\
\hline Yashthi \\
\hline Shunthi \\
\hline Dalchini
\end{tabular}


Table 6:

\begin{tabular}{|l|l|}
\hline Triphala Guggulu & \\
\hline S.No. & Drugs \\
\hline 1 & Haritaki \\
\hline 2 & Vibhitaki \\
\hline 3 & Aamalaki \\
\hline 4 & Pippali \\
\hline 5 & Guggulu \\
\hline
\end{tabular}

\section{Table 7:}

\begin{tabular}{|l|l|}
\hline Netramritam Eyedrop & \\
\hline S.No. & Drugs \\
\hline 1 & Lodhra \\
\hline 2 & Camphor \\
\hline 3 & Padmaka \\
\hline 4 & Sevyam \\
\hline 5 & Sasi \\
\hline 6 & Himambu \\
\hline
\end{tabular}

The Ingredients of Patoladi Ghrita eyedrop is similar to that of patoladi ghrita.

\section{RESULTS-}

Table 8: Visual acuity

\begin{tabular}{|c|c|c|c|}
\hline & BT & After Nasya and Netra pariseka & After Tarpana \\
\hline \multicolumn{4}{|c|}{ Right Eye } \\
\hline DV & $6 / 24$ & $6 / 24$ & $6 / 12$ \\
\hline PH & $6 / 9$ & $6 / 9$ & $6 / 6$ \\
\hline BCVA & $6 / 12$ & $6 / 9$ & $6 / 6$ \\
\hline \multicolumn{4}{|c|}{ Left Eye } \\
\hline DV & $6 / 24$ & $6 / 24$ & $6 / 12$ \\
\hline PH & $6 / 9$ & $6 / 9$ & $6 / 6$ \\
\hline BCVA & $6 / 12$ & $6 / 9$ & $6 / 6$ \\
\hline
\end{tabular}

No adverse events were reported during the study. There was an improvement in his visual acuity in both eyes and watering from both eyes and pain in both eyes. Spectacle correction after treatment: Distance Vision

Right Eye - -0.25DS, Left Eye - -0.25DS

\section{DISCUSSION}

Timira is treated by Snehana, Virechana, Raktamokshana, Nasya, Anjana, Shirobasti, Tarpana, Lepa, Seka that are to be followed repeatedly. Among these Nasya, Seka, Tarpana followed in this case. Based on symptoms, Myopia can be correlated with Vatika Timira. Hence the line of management of Vatika Timira was adopted. Nasya was done with Shatbindu taila. Ingredients of shadbindu taila act as vata and kapha dosha shamaka, hence it destroys the pathology of Timira. Nasya is one of the important karmas of Panchakarma which is used for all diseases of the Urdhwajatrugata. The procedure of nasya is that it can be used for Shaman as well as for Shodhan of Doshas. It can eliminate neurological and psychological problems when used independently or with any other Karmas. As stated, "dwaram hi shirso Nasa" [10] according to this, nasya aaushadhi stimulates the Shringataka marma, brain and nervous system by going to the nostril and at the same time, the nasya is absorbed in the entire Urdhwaang and provides nutrition to the head, brain, nose, ears, eyes, mouth etc. Nasya karma of Ayurveda proves to be beneficial from the history of treatment and prevention measures given to the persons suffering from 
Urdhwajatrugata disease. Netra Pariseka procedure, a thin stream of liquid is poured around the eyes from a height of about four inches ${ }^{[11]}$. The lukewarm medicated liquid is needed throughout the procedure. In this study Triphala and Yashthi churna both are having Chakshusya properties hence it is useful in destroying the pathology of Timira. Tarpana was completed with patoladi ghrita. It is indicated in Chakshu Rogas. Patoladi ghrita appears to be predominantly Vatashamaka followed Pitta and Kaphashamaka. Thus, the overall effect of the drug is Vata Pradhan Tridosha Shamaka and hence it destroys the pathology of Timira ${ }^{[12]}$. Tarpana is topical therapy in which medicated ghee is retained in the eyes by a retention wall made from Urada dal flour ${ }^{[13]}$ which has been recommended in improving the Drishtibala of the eyes as it has Roga Nivruti and Vyadhi Vinashakar properties. In the present study, Patoladi Ghrita is adopted as it has Snehana and Ropana properties which may help in improving the vision. Netramritam eyedrop gives a cooling effect to the eyes and it is also useful in watering eyes ${ }^{[14]}$. Patoladi ghrita eyedrop is also having snehana properties hence it is extremely useful in Vataja Timira. Triphala guggulu has an anti-inflammatory effect. Triphala has also Chakshusya properties.

\section{CONCLUSION}

Netra Priseka, Nasya and Tarpana with Eyedrops and Internal Medicines had shown useful, improvement in Visual acuity and other symptoms and decrease the spectacle power. This study shows importance of Ayurveda in Myopia. Study on a larger number of patients and long duration to draw more significant conclusions. Awareness should be created for the effectiveness of Ayurveda in such types of diseases where modern medicine has a limited role. The study concludes that this line of treatment improves the quality of the vision area.

\section{REFERENCES}

1. Dr Anant Ram Sharma, Susruta Samhita, Susrutavimarsini Hindi commentary, Chaukhambha Surbharti Publication Varanasi, Reprint 2015, Uttartantra Page No. 55
2. Dr Anant Ram Sharma, Susruta Samhita, Susrutavimarsini Hindi commentary, Chaukhambha Surbharti Publication Varanasi, Reprint 2015, Uttartantra Page No. 57

3. Dr A.K. Khurana, Comprehensive Ophthalmology, Jaypee brothers, Reprint 2015, Page no.38

4. Dr A.K. Khurana, Comprehensive Ophthalmology, Jaypee brothers, Reprint 2015, Page no.39

5. Dr A.K. Khurana, Comprehensive Ophthalmology, Jaypee brothers, Reprint 2015, Page no.41

6. Kaviraj Atridev Gupta, Ashtanghridyam, Vidyotani Hindi commentary, Chaukhambha Publication Varanasi, Reprint vi. sam. 2065, Uttartantra, Page No.671

7. Pro.Siddhi Nandan Mishra, Bhaisajya Ratnavali, Siddhiprada Hindi commentary Chaukhambha Subharati Prakashan Varanasi, Reprint 2021, Shiro rogadhikara, Page No.1020

8. Dr Shrimati Shailaja Shrivastava, Sharangadhara Samhita, Jivanprada Hindi commentary, Chaukhambha Orientalia, Reprint 2017, Madhyamakhanda, Page No.205.

9. http://www.ayurmedinfo.com

10. Pt. kashinath shastri and Dr Gorakhanath, Charaka Samhita, Vidyotini Hindi commentary, Chaukhambha Bharti Academy Varanasi, Reprint 2016, Sidhdisthana Page No. 1070

11. Dr Shrimati Shailaja Shrivastava, Sharangadhara Samhita, Jivanprada Hindi commentary, Chaukhambha Orientalia, Reprint 2017, Madhyamakhanda, Page No.477.

12. Kaviraj Atridev Gupta, Ashtanghridyam, Vidyotani Hindi commentary, Chaukhambha Publication Varanasi, Reprint vi. sam. 2065, Uttartantra, Page No.671

13. Dr Anant Ram Sharma, Susruta Samhita, Susrutavimarsini Hindi commentary, Chaukhambha Surbharti Publication Varanasi, Reprint 2015, Uttartantra Page No. 124

14. http://www.ayurmedinfo.com

\section{Source of Support: Nil \\ Conflict of Interest: None Declared}

How to cite this URL: Kavita Rathore \& Shamsa Fiaz: A Single Case Study On The Effect Of Ayurvedic Management In Timira W.S.R. To Myopia - A Case Study. International Ayurvedic Medical Journal \{online\} 2021 \{cited July, 2021\} Available from: http://www.iamj.in/posts/images/upload/1549_1554.pdf 